\title{
Colonisation of the urethra with Streptococcus pneumoniae: a case report
}

\author{
ROBERT C NOBLE \\ From the Division of Infectious Diseases, Department of Medicine, University of Kentucky College of \\ Medicine, Lexington, Kentucky, United States
}

SUMMARY A 25 year old man developed mild urethritis and urethral colonisation with Streptococcus pneumoniae five days after a single orogenital sexual contact. The diagnosis was suspected because of the appearance of Gram positive diplococci in the urethral exudate. The incidence of urethral infection with $S$ pneumoniae is not known. Pneumococci are unlikely to grow on the routine selective media used to identify Neisseria gonorrhoeae.

\section{Introduction}

Bacterial colonisation of the distal urethra usually consists of small numbers of coagulase negative staphylococci, micrococci, or corynebacteria. ${ }^{12}$ This report describes a young man who had mild urethritis and urethral colonisation with Streptococcus pneumoniae one week after a single orogenital sexual contact with a new sexual partner.

\section{Case report}

After a three year monogomous relationship with his girlfriend, a 25 year old white unmarried man had a single sexual encounter with another woman consisting of orogenital and penile-vaginal contact. His previous orogenital sexual contact had been with his girlfriend about two months earlier. Five days after his last sexual contact, he noted a clear discharge from his urethra and mild discomfort when he urinated. These symptoms resolved within one day, but because of concern that he might have a sexually transmitted disease, he requested evaluation seven days after the sexual contact. His physical examination showed no abnormality. He was circumcised. The figure shows a Gram stained smear of a urethral swab (Calgiswab; Biomedical Operations, Inolex Division, American Can Company, Glenwood, Illinois, USA). Because of the presence of Gram positive, lancet shaped diplococci in the urethral exudate, the exudate was cultured on sheep blood

Address for reprints: Dr Robert C Noble, Division of Infectious Diseases, Department of Medicine, University of Kentucky College of Medicine, Lexington, Kentucky 40536, USA

Accepted for publication 28 February 1985 agar and also on Martin-Lewis medium. ${ }^{3}$ A pure culture of Streptococcus pneumoniae grew on the blood agar. There was no growth on the MartinLewis medium. The patient was treated with oral ampicillin $3.5 \mathrm{~g}$ with $1 \mathrm{~g}$ probenecid. One week later, urethral and pharyngeal cultures were negative for pneumococci. The urethral culture grew a few colonies of Straphylococcus epidermidis. The patient's latest sexual partner could not be located; the young man has remained without symptoms.

\section{Discussion}

Streptococcus pneumoniae is not mentioned among the normal or pathogenic flora of the urethra in standard references. ${ }^{24}$ The source of the patient's pneumococcus was probably the oral secretions of his last sexual partner. Pneumococci transiently colonise the pharynx of healthy people. ${ }^{56}$ During an 80 week period, $39 \%$ of members of 29 families acquired pneumococci in their throats. ${ }^{5}$ Although some people were carriers for several months, a follow up study found that the modal duration of carriage was two weeks for pneumococci types 3 and $19 .{ }^{6}$ It is unfortunate that specimens could not be taken from the patient's sexual partner for culture to see if pneumococci were present in her pharynx.

The presence of pharyngeal microflora in the male urethra is not without precedent. Neisseria meningitidis has been isolated from the urethra of men. ${ }^{78}$ Orogenital sexual contact may play a part in the transmission of genital meningococcal infection, as it is more commonly present in homosexual men. Colonisation of the male urethra by Haemophilus species may be the result of orogenital contact, but the biotypes of genital and respitatory isolates 


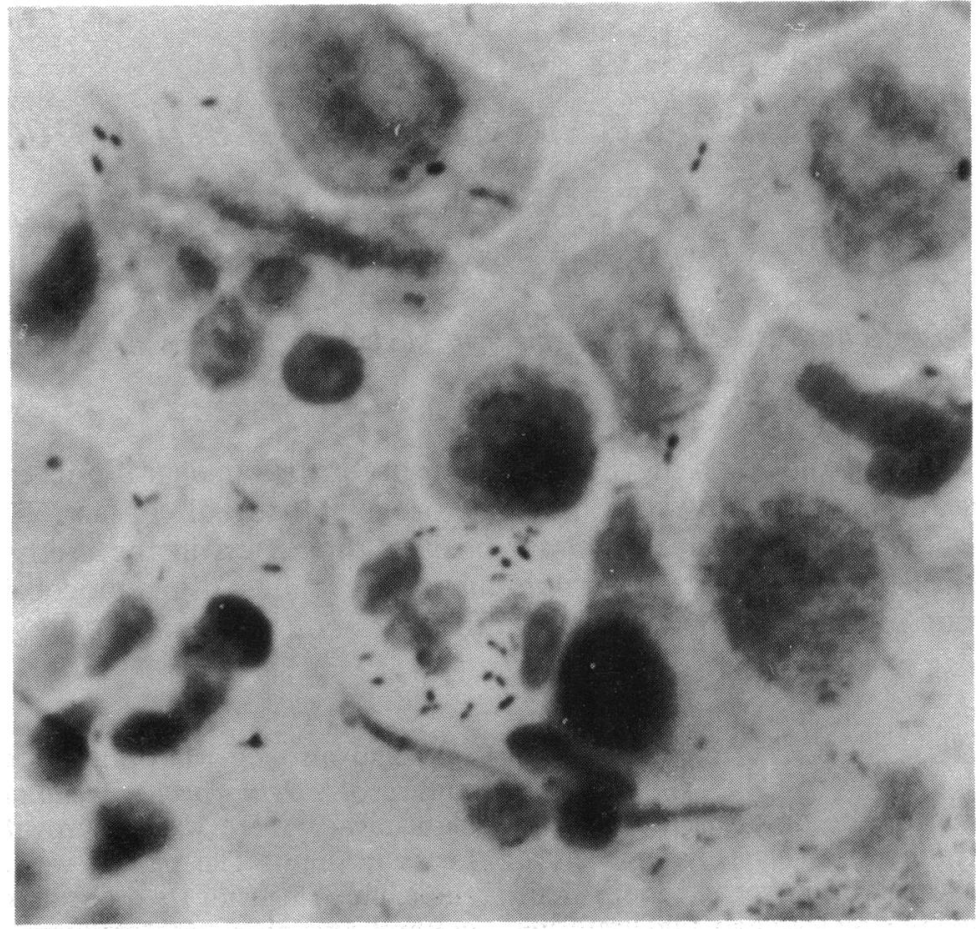

FIGURE Gram stained urethral exudate with leucocyte associated Gram positive, lancet shaped diplococci ( $\times 1500$ original magnification).

differ..$^{10}$ The intention of this report is to encourage interested doctors to use a non-selective culture medium if they see what appear to be pneumococci on examination of Gram stained urethral exudate. Pneumococci will not grow on the media commonly used for routine isolation of Neisseria gonorrhoeae, such as Martin-Lewis medium, ${ }^{3}$ Thayer-Martin medium, ${ }^{11}$ or New York City medium, ${ }^{11}$ because these media contain antibiotics that inhibit the pneumococcus.

The report published here does not implicate the pneumococcus as an important cause of urethritis, but shows that this organism may colonise the male urethra.

\section{References}

1. Philpot VB. The bacterial flora of urine specimens from normal adults. $J$ Urol 1956; 75:562-8.

2. Cohen MS, Colleen S, Mardh P-A. Mucosal defenses. In Holmes KK, Mårdh P-A, Sparling PF, Wiesner PJ, eds. Sexually transmitted diseases. St Louis: McGraw-Hill Book Company, 1984:173-83.
3. Martin JE, Lewis JS. Ansimycin: improved antimycotic activity in modified Thayer-Martin medium. Public Health Laboratory 1977;35: 53-62.

4. King AJ, Nicol C. Venereal diseases. 3rd ed. London: Baillière Tindall, 1975:257-69.

5. Suh RH, Felman HA. Pneumococcal types detected in throat cultures from a population of "normal families". Am J Med Sci 1965; 250:424-7.

6. Dowling JN, Sheehe PR, Felman HA. Pharyngeal pneumococcal acquisitions in "normal" families. $J$ Infect Dis 1971; 124:9-17.

7. Faur YC, Weisburd MH, Wilson ME. Isolation of Neisseria meningitidis from the genito-urinary tract and anal canal. $J$ Clin Microbiol 1975; 2:178-82.

8. Givan KF, Thomas BW, Johnston AG. Isolation of Neisseria meningitidis from the urethra, cervix, and anal canal: further observations. British Journal of Venereal Diseases 1977; 53: 109-12.

9. Messing M, Sottnek FO, Biddle JW, Schlater LK, Kramer MA Kraus SJ. Isolation of Haemophilus species from the genital tract. Sex Transm Dis 1983; 10:56-61.

10. Albritton WL, Brunton JL, Meier M, Bowman MN, Slaney LA. Haemophilus influenzae: comparison of respiratory tract isolates with genitourinary tract isolates. J Clin Microbiol 1982; 16:826-31.

11. Vera HD, Power DA. Culture media. In: Lennette EH, Balows A, Hausler WJ, Truant JP, eds. Manual of clinical microbiology. 3rd ed. Washington, DC: American Society for Microbiology, 1980;965-99. 